\title{
Clonagem e células-tronco
}

\author{
MAYANA ZATZ
}

\section{0 que é clonagem?}

A CLONAGEM É U M mecanismo comum de propagação da espécie em plantas ou bactérias. D e acordo com Webber (1903) um clone é definido como uma população de moléculas, células ou organismos que se originaram de uma única célula e que são idênticas à célula original e entre elas. Em humanos, os clones naturais são os gêmeos idênticos que se originam da divisão de um óvulo fertilizado. A grande revolução da Dolly, que abriu caminho para a possibilidade de clonagem humana, foi a demonstração, pela primeira vez, de que era possível clonar um mamífero, isto é, produzir uma cópia geneticamente idêntica, a partir de uma célula somática diferenciada. Para entendermos porque esta experiência foi surpreendente, precisamos recordar um pouco de embriologia.

Todos nós já fomos uma célula única, resultante da fusão de um óvulo e um espermatozóide. E sta primeira célula já tem no seu núcleo o D N A com toda a informação genética para gerar um novo ser. 0 D N A nas células fica extremamente condensado e organizado em cromossomos. Com exceção das nossas células sexuais, o óvulo e o espermatozóide que têm 23 cromossomos, todas as outras células do nosso corpo têm 46 cromossomos. Em cada célula, temos 22 pares que são iguais nos dois sexos, chamados autossomos e um par de cromossomos sexuais: $X X$ no sexo feminino e $X Y$ no sexo masculino. Estas células, com 46 cromossomos, são chamadas células somáticas. Voltemos agora à nossa primeira célula resultante da fusão do óvulo e do espermatozóide. Logo após a fecundação, ela começa a se dividir: uma célula em duas, duas em quatro, quatro em oito e assim por diante. Pelo menos até a fase de oito células, cada uma delas é capaz de se desenvolver em um ser humano completo. São chamadas de totipotentes. $\mathrm{N}$ a fase de oito a dezesseis células, as células do embrião se diferenciam em dois grupos: um grupo de células externas que vão originar a placenta e os anexos embrionários, e uma massa de células internas que vai originar o embrião propriamente dito. Após 72 horas, este embrião, agora com cerca de cem células, é chamado de blastoci sto. É nesta fase que ocorre a implantação do embrião na cavidade uterina. As células internas do blastocisto vão originar as centenas de tecidos que compõem o corpo humano. São chamadas de célulastronco embri onáriaspluri potentes A partir de um determinado momento, estas células somáticasque ainda são to das iguais - começam a diferenciar-se nos vários tecidos que vão compor o organismo: sangue, fígado, músculos, cérebro, ossos etc. O s genes que controlam esta diferenciação e o processo pelo qual isto ocorre ainda são um mistério. 0 que sabemos é que uma vez diferenciadas, as células somáticas per- 
dem a capacidade de originar qualquer tecido. As células descendentes de uma célula diferenciada vão manter as mesmas características daquela que as originou, isto é, células de fígado vão originar células de fígado, células musculares vão originar células musculares e assim por diante. A pesar de o número de genes e de o D N A ser igual em todas as células do nosso corpo, os genes nas células somáticas diferenciadas se expressam de maneiras diferentes em cada tecido, isto é, a expressão gênica é específica para cada tecido. Com exceção dos genes responsáveis pela manutenção do metabolismo celular (hou sekeeping genes) que se mantêm ativos em todas as células do organismo, só irão funcionar em cada tecido ou órgão os genes importantes para a manutenção deste. O s outros se mantêm "silenciados" ou inativos.
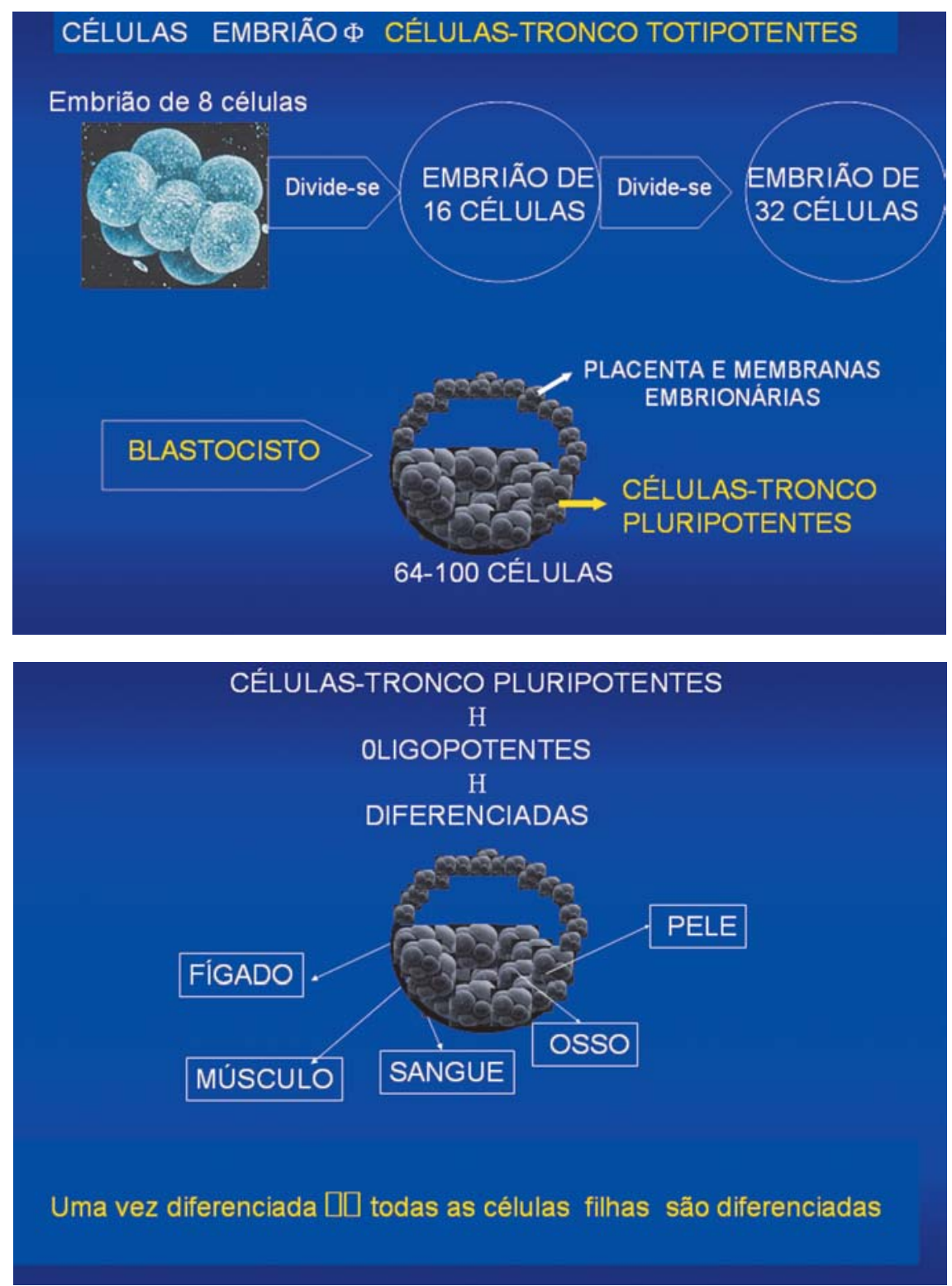


\section{0 processo de clonagem reprodutiva}

A grande notícia da D olly foi justamente a descoberta de que uma célula somática de mamífero, já diferenciada, poderia ser reprogramada ao estágio inicial e voltar a ser totipotente. Isto foi conseguido através da transferência do núcleo de uma célula somática da glândula mamária da ovelha que originou a D olly para um óvulo enucleado. Surpreendentemente, este começou a comportar-se como um óvulo recém-fecundado por um espermatozóide. I sto provavelmente ocorreu porque o óvulo, quando fecundado, tem mecanismos, para nós ainda desconhecidos, para reprogramar o DN A de modo a tornar todos os seus genes novamente ativos, o que ocorre no processo normal de fertilização.

Para a obtenção de um clone, este óvulo enucleado no qual foi transferido o núcleo da célula somática foi inserido em um útero de uma outra ovel ha. No caso da clonagem humana reprodutiva, a proposta seria retirar-se o núcleo de uma célula somática, que teo ricamente poderia ser de qualquer tecido de uma criança ou adulto, inserir este núcleo em um óvulo e implantá-lo em um útero (que funcionaria como uma barriga de aluguel). Se este óvulo se desenvolver teremos um novo ser com as mesmas características físicas da criança ou adulto de quem foi retirada a célula somática. Seria como um gêmeo idêntico nascido posteriormente.

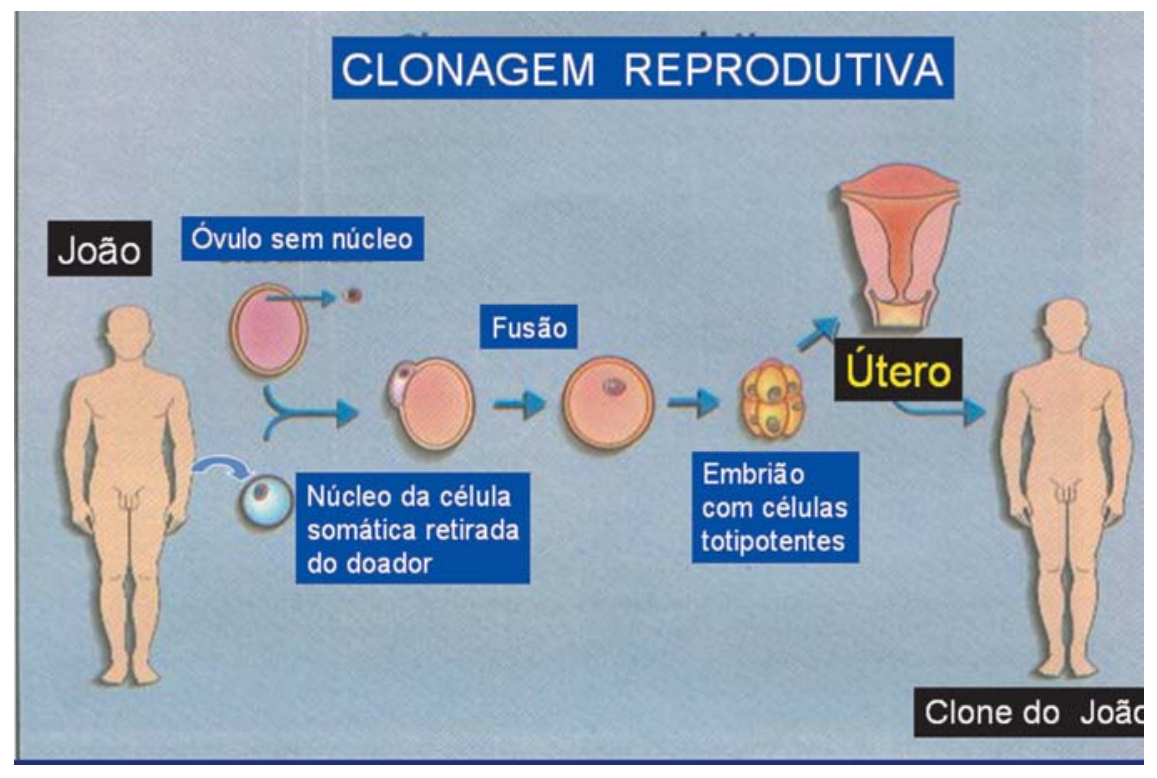

Já sabemos que não é um processo fácil. Dolly só nasceu depois de 276 tentativas que fracassaram. Além disso, dentre as 277 células "da mãe de D olly" que foram inseridas em um óvulo sem núcleo, 90\% não alcançaram nem o estágio de blastocisto. A tentativa posterior de clonar outros mamíferos tais como camundongos, porcos, bezerros, um cavalo e um veado também tem mostrado uma eficiência muito baixa e uma proporção muito grande de abortos e embriões malformados. Penta, a primeira bezerra brasileira clonada a partir de uma célula 
somática morreu adulta, em 2002, com um pouco mais de um mês. Ainda em 2002 , foi anunciada a clonagem do copycat o primeiro gato de estimação clonado a partir de uma célula somática adulta. Para isto foram utilizados 188 óvulos que geraram 87 embriões e apenas um animal vivo. $\mathrm{N}$ a realidade, experiências recentes, com diferentes tipos de animais, têm mostrado que esta reprogramação dos genes, para o estágio embrionário, o qual originou D olly, é extremamente difícil.

O grupo liderado por I an Wilmut, o cientista escocês que se tornou famoso por esta experiência, afirma que praticamente todos os animais que foram clonados nos últimos anos a partir de células não embrionárias estão com problemas (R hind, 2003). Entre os diferentes defeitos observados nos pouquíssimos animais que nasceram vivos após inúmeras tentativas, observam-se: placentas anormais, gigantismo em ovelhas e gado, defeitos cardíacos em porcos, problemas pulmonares em vacas, ovelhas e porcos, problemas imunológicos, fal ha na produção de leucócitos, defeitos musculares em carneiros. De acordo com $\mathrm{H}$ ochedlinger e Jaenisch (2003), os avanços recentes em clonagem reprodutiva permitem quatro conclusões importantes: 1) a maioria dos clones morre no início da gestação; 2) os animais clonados têm defeitos e anormalidades semelhantes, independentemente da célula doadora ou da espécie; 3) essas anormalidades provavelmente ocorrem por falhas na reprogramação do genoma; 4) a eficiência da clonagem depende do estágio de diferenciação da célula doadora. D e fato, a clonagem reprodutiva a partir de células embrionárias tem mostrado uma eficiência de dez a vinte vezes maior, provavelmente porque os genes que são fundamentais no início da embriogênese estão ainda ativos no genoma da célula doadora (H ochedlinger e J aenisch, 2003).

É interessante que, dentre todos os mamíferos que já foram clonados, a eficiência é um pouco maior em bezerros (cerca de 10\% a 15\%). Por outro lado, um fato intrigante é que ainda não se tem notícias de macaco ou cachorro que tenha sido clonado. Talvez seja por isso que a cientista inglesa Ann M CLaren tenha afirmado que as falhas na reprogramação do núcleo somático possam se constituir em uma barreira intransponível para a clonagem humana.

M esmo assim, pessoas como o médico italiano Antinori ou a seita dos raelianos defendem a clonagem humana, um procedimento que tem sido proibido em todos os países. D e fato, um documento assinado em 2003 pelas academias de ciências de 63 países, inclusive o Brasil, pedem o banimento da clonagem reprodutiva humana. 0 fato é que a simples possibilidade de clonar humanos tem suscitado discussões éticas em todos os segmentos da sociedade, tais como: Por que clonar? Q uem deveria ser clonado? Q uem iria decidir? Q uem será o pai ou a mãe do clone? 0 que fazer com os clones que nascerem defeituosos?

$\mathrm{N}$ a realidade, o maior problema ético atual é o enorme risco biológico associado à clonagem reprodutiva. No meu entender, seria a mesma coisa que discutir os prós e os contras em relação à liberação de uma medicação nova, cujos efeitos são devastadores e ainda totalmente incontroláveis. 
A pesar de todos estes argumentos contra a clonagem humana reprodutiva, experiências com animais clonados têm nos ensinado muito acerca do funcionamento celular. Por outro lado, a tecnologia de transferência de núcleo para fins terapêuticos, a chamada cl onagem tera pêutica, po derá ser extremamente útil para obtenção de células-tronco.

\section{A técnica de clonagem terapêutica para obtenção de células-tronco}

Se em vez de inserirmos em um útero o óvulo cujo núcleo foi substituído por um de uma célula somática deixarmos que ele se divida no laboratório teremos a possibilidade de usar estas células - que na fase de blastocisto são pluripotentes - para fabricar diferentes tecidos. I sto abrirá perspectivas fantásticas para futuros tratamentos, porque hoje só se consegue cultivar em laboratório células com as mesmas características do tecido do qual foram retiradas. É importante que as pessoas entendam que, na clonagem para fins terapêuticos, serão gerados só tecidos, em laboratório, sem implantação no útero. N ão se trata de clonar um feto até alguns meses dentro do útero para depois lhe retirar os órgãos como alguns acreditam. Também não há porque chamar esse óvulo de embrião após a tranferência de núcleo porque ele nunca terá esse destino.

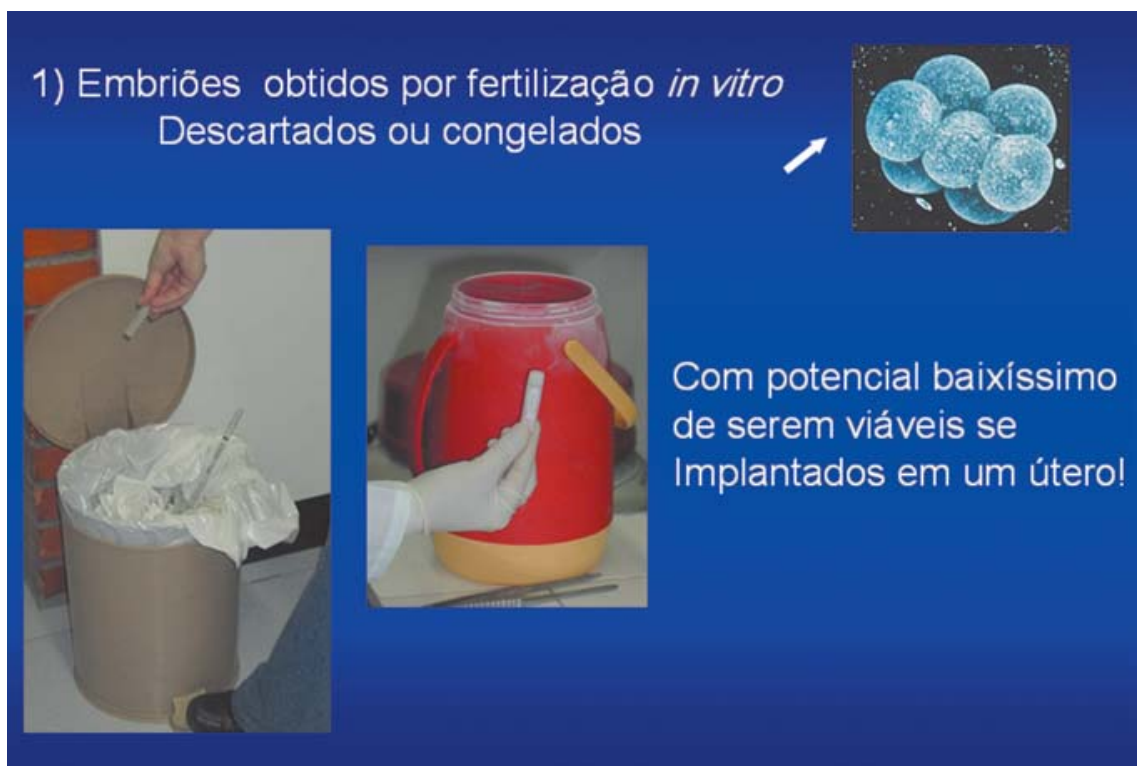

U ma pesquisa publicada na revista Sciences por um grupo de cientistas coreanos (H wang e col., 2004) confirma a possibilidade de obter-se células-tronco pluripotentes a partir da técnica de clonagem terapêutica ou transferência de núcleos (TN). O trabalho foi feito graças a participação de dezesseis mulheres voluntárias que doaram, ao todo, 242 óvulos e células “cumulus" (células que ficam ao redor dos óvulos) para contribuir com pesquisas visando à clonagem 
terapêutica. As células cumulus, que já são células diferenciadas, foram transferidas para os óvulos dos quais haviam sido retirados os próprios núcleos. D entre esses, $25 \%$ conseguiram se dividir e chegar ao estágio de blastocisto, portanto, capazes de produzir linhagens de células-tronco pluripotentes.

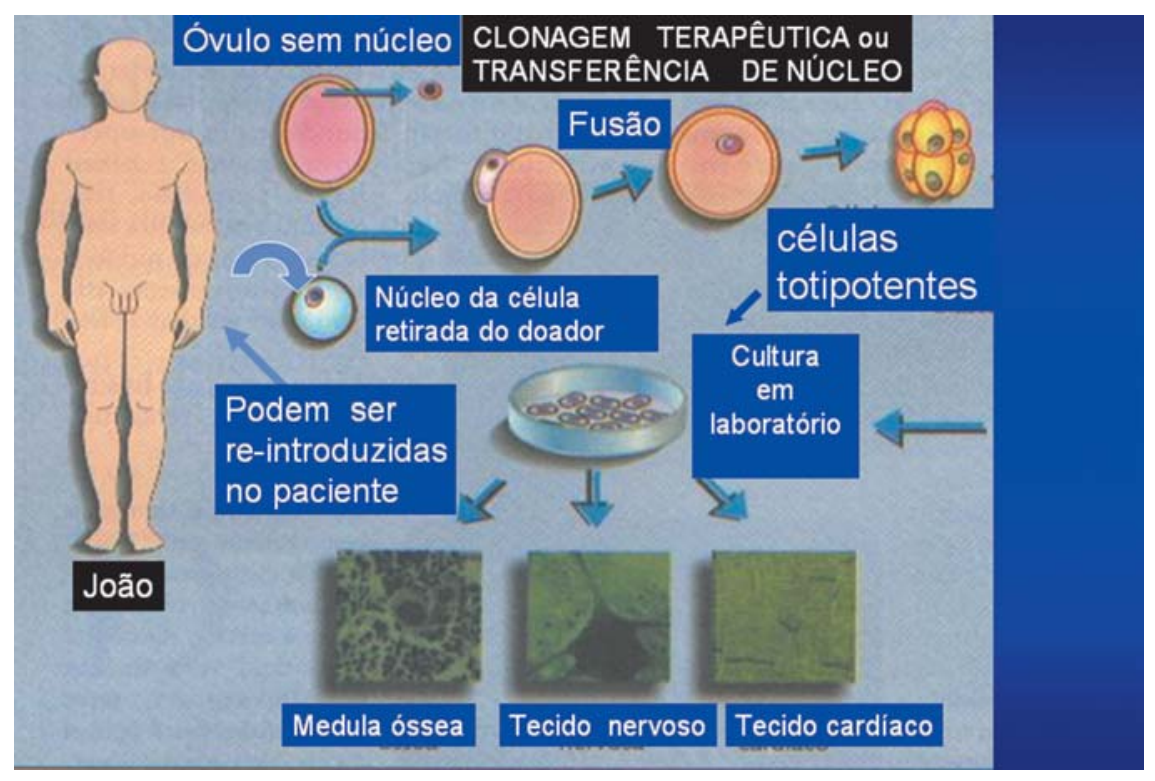

A clonagem terapêutica teria a vantagem de evitar rejeição se o doador fosse a própria pessoa. Seria o caso, por exemplo, de reconstituir a medula em alguém que se tornou paraplégico após um acidente ou para substituir o tecido cardíaco em uma pessoa que sofreu um infarto. Entretanto, esta técnica tem suas limitações. 0 doador não poderia ser a própria pessoa quando se tratasse de alguém afetado por doença genética, pois a mutação patogênica causadora da doença estaria presente em todas as células. No caso de usar-se linhagens de células-tronco embrionárias de outra pessoa, ter-se-ia também o problema da compatibilidade entre o doador e o receptor. Seria o caso, por exemplo, de alguém afetado por distrofia muscular progressiva, pois haveria necessidade de se substituir seu tecido muscular. Ele não poderia utilizar-se de suas próprias células-tronco, mas de um doador compatível que poderia, eventualmente, ser um parente próximo. Além disso, não sabemos se, no caso de células obtidas de uma pessoa idosa afetada pelo mal de Alzheimer, por exemplo, se as células clonadas teriam a mesma idade do doador ou se seriam células jovens. U ma outra questão em aberto diz respeito à reprogramação dos genes que poderiam inviabilizar 0 processo dependendo do tecido ou do órgão a ser substituído. Em resumo, por mais que sejamos favoráveis à clonagem terapêutica, trata-se de uma tecnologia que necessita de muita pesquisa antes de ser aplicada no tratamento clínico. Por este motivo, a grande esperança, a curto prazo, para terapia celular, vem da utilização de células-tronco de outras fontes 


\section{Terapia celular com outras fontes de células-tronco}

\section{a) Indi vídu os adultos}

Existem células-tronco em vários tecidos (como medula óssea, sangue, fígado) de crianças e adultos. Entretanto, a quantidade é pequena e não sabemos ainda em que tecidos são capazes de se diferenciar. Pesquisas recentes mostraram que células-tronco retiradas da medula de indivíduos com problemas cardíacos foram capazes de reconstituir o músculo do seu coração, o que abre perspectivas fantásticas de tratamento para pessoas com problemas cardíacos. M as a maior limitação da técnica, do autotran splanteé que ela não serviria para portadores de doenças genéticas. É importante lembrar que as doenças genéticas afetam 3-4\% das crianças que nascem. $\mathrm{O}$ u seja, mais de cinco milhões de brasileiros para uma população atual de 170 milhões de pessoas. É verdade que nem todas as doenças genéticas poderiam ser tratadas com células-tronco, mas se pensarmos somente nas doenças neuromusculares degenerativas, que afetam uma em cada mil pessoas, estamos falando de quase duzentas mil pessoas.

\section{b) Cordão u mbilical e placenta}

Pesquisas recentes vêm mostrando que o sangue do cordão umbilical e da placenta são ricos em células-tronco. Entretanto, também não sabemos ainda qual é o potencial de diferenciação dessas células em diferentes tecidos. Se as pesquisas com células-tronco de cordão umbilical proporcionarem os resultados esperados, isto é, se forem realmente capazes de regenerar tecidos ou órgãos, esta será certamente uma notícia fantástica, porque não envolveria questões éticas. Teríamos que resolver então o problema de compatibilidade entre as célulastronco do cordão doador e do receptor. Para isto será necessário criar, com a maior urgência, bancos de cordão públicos, à semelhança dos bancos de sangue. I sto porque sabe-se que, quanto maior o número de amostras de cordão em um banco, maior a chance de se encontrar um compatível. Experiências recentes já demonstraram que o sangue do cordão umbilical é o melhor material para substituir a medula em casos de leucemia. Por isso, a criação de bancos de cordão é uma prioridade que já se justifica somente para o tratamento de doenças sangüíneas, mesmo antes de confirmarmos o resultado de outras pesquisas.

\section{c) Célulasembrionárias}

Se as células-tronco de cordão tiverem a potencialidade desejada, a alternativa será o uso de células-tronco embrionárias obtidas de embriões não utilizados que são descartados em clínicas de fertilização. O s opositores ao uso de células embrionárias para fins terapêuticos argumentam que isto poderia gerar um comércio de óvulos ou que haveria destruição de "embriões humanos" e não é ético destruir uma vida para salvar outra. 


\section{Aspectos éticos}

Apesar de todos esses argumentos, o uso de células-tronco embrionárias para fins terapêuticos, obtidas tanto pela transferência de núcleo como de embriões descartados em clínicas de fertilização, é defendido pelas inúmeras pessoas que poderão se beneficiar por esta técnica e pela maioria dos cientistas. As63 academias de ciência do mundo que se posicionaram contra a clonagem reprodutiva defendem as pesquisas com células embrionárias para fins terapêuticos. E $m$ relação aos que acham que a clonagem terapêutica pode abrir caminho para clonagem reprodutiva devemos lembrar que existe uma diferença intransponível entre os dois procedimentos: a implantação ou não em um útero humano. Basta proibir a implantação noúter o! Se pensarmos que qualquer célula humana pode ser teoricamente clonada e gerar um novo ser, poderemos chegar ao exagero de achar que toda vez que tiramos a cutícula ou arrancamos um fio de cabelo, estamos destruindo uma vida humana em potencial. Afinal, o núcleo de uma célula da cutícula poderia ser colocada em um óvulo enucleado, inserido em um útero e gerar umanova vida!

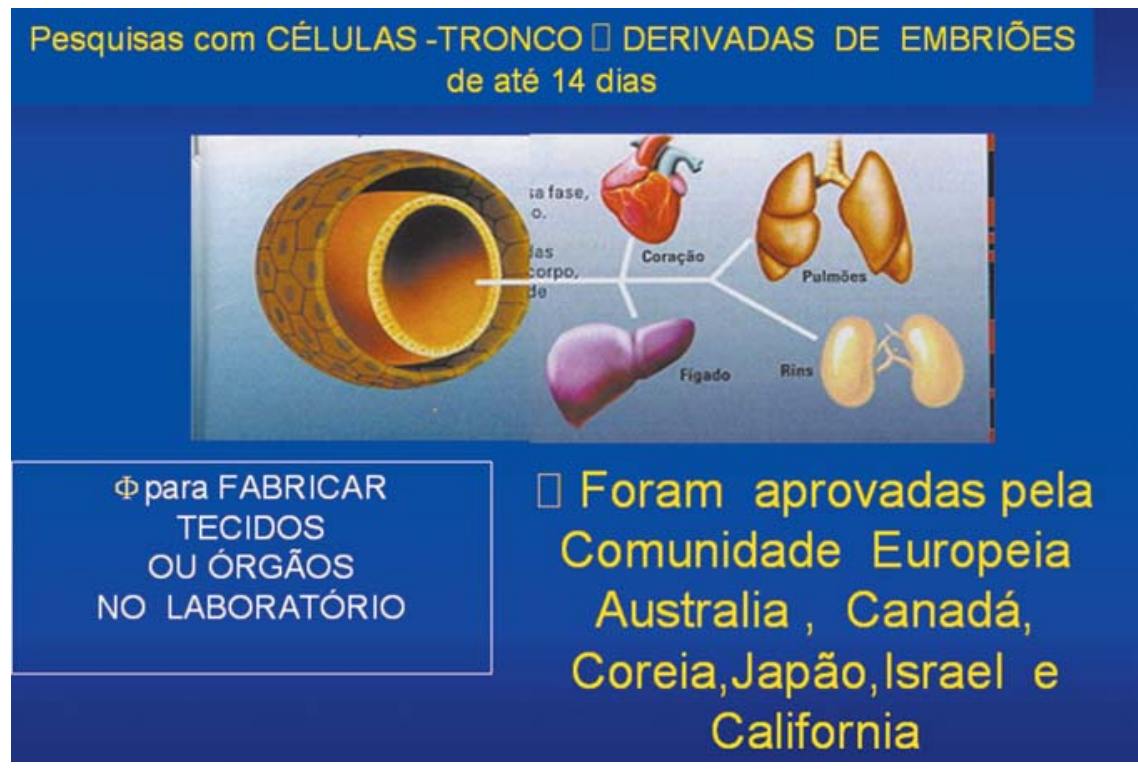

Por outro lado, a cultura de tecidos é uma prática comum em laboratório, apoiada por todos. A única diferença, no caso, seria o uso de óvulos (que quando não fecundados são apenas células) que permitiriam a produção de qualquer tecido no laboratório. O u seja, em vez de poder produzir-se apenas um tipo de tecido, já especializado, o uso de óvulos permitiria fabricar qualquer tipo de tecido. 0 que há de anti-ético nisso?

Q uanto ao comércio de óvulos, não seria a mesma coisa que ocorre hoje com transplante de órgãos? N ão é mais fácil doar um óvulo do que um rim? Cada uma de nós pode se perguntar: você doaria um óvulo para ajudar alguém? Para salvar uma vida? 


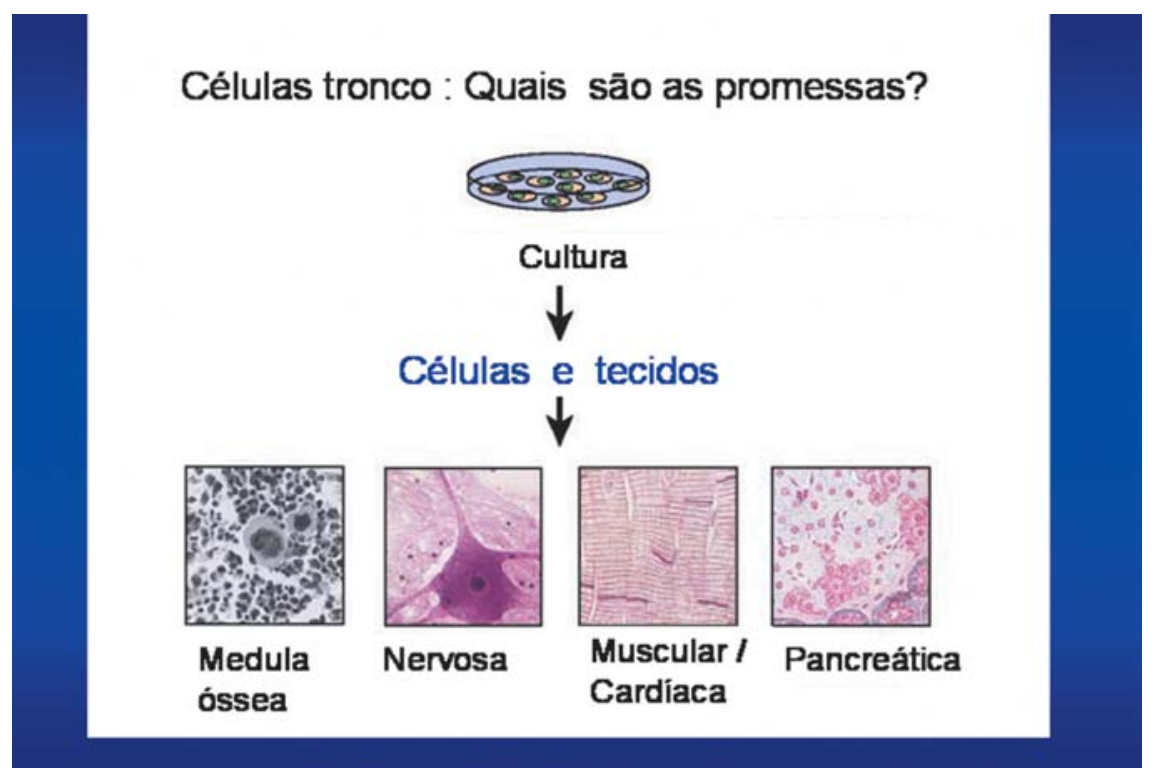

Em relação à destruição de "embriões humanos", novamente devemos lembrar que estamos falando de cultivar tecidos ou, futuramente, órgãos a partir de embriões que são normalmente descartados, que nunca serão inseridos em um útero. Sabemos que $90 \%$ dos embriões gerados em clínicas de fertilização e que são inseridos em um útero, nas melhores condições, não geram vida. Além disso, um trabalho recente ( $M$ italipova et al., 2003) mostrou que células obtidas de embriões de má qualidade, que não teriam potencial para gerar uma vida, mantêm a capacidade de gerar linhagens de células-tronco embrionárias e portanto, de gerar tecidos.Em resumo, é justo deixar morrer uma criança ou um jovem afetado por uma doença neuromuscular letal para preservar um embrião cujo destino é o lixo? U m embrião que, mesmo que fosse implantado em um útero, teria um potencial baixíssimo de gerar um indivíduo? Ao usar célulastronco embrionárias para regenerar tecidos em uma pessoa condenada por uma doença letal, não estamos, na realidade, criando vida? I sso não é comparável ao que se faz hoje em transplante quando se retiram os órgãos de uma pessoa com morte cerebral (mas que poderia permanecer em vida vegetativa)

É extremamente importante que as pessoas entendam a diferença entre clonagem humana, clonagem terapêutica e terapia celular com células-tronco embrionárias ou não. A maioria dos países da comunidade Européia, $0 \mathrm{C}$ anadá, a Austrália, o J apão, a C hina, a C oréia e I srael aprovaram pesquisas com células embrionárias de embriões há pouco tempo. Essa é também a posição das academias de ciência de 63 países, inclusive o Brasil. É fundamental que a nossa legislação também aprove estas pesquisas porque elas poderão salvar inúmeras vidas! 


\section{Bibliografia}

H OCHEDLINGER, K. e JAEN ISH, R. "N uclear Transplantation, E mbryonic Stem Cells and the Potential for Cell Therapy". N . Engl. Journal of M edicine, 349:275212, 2003.

MITALIPOVA, M.; CALHOUN, J.; SHIN, S.; WININGER, D. et al. "H uman Embryonic Stem Cells L ines D erived from D iscarded Embryos". Stem Cells, 21:521526, 2003.

RHIND, S. M.; TAYLOR, J. E.; DE SOU SA, P. A.; KiNg, T. U . I.; M CGARRY, M . e WI LM U T, I. "H uman Cloning: Can it be M ade Safe?" N ature R eviews, 4:855-864, 2003.

H WAN G, S. W.; RYU, Y. J.; PARK, J. H .; PARK, E. S.; LEE, E. G.; KO O, J. M . et al. "Evidence of a Plurpotent Embryonic Stem Cell Line Derived from a Cloned Blastocyst". Scienceexpress, 12 fev. 2004.

RESU M O - APESAR do muito que se tem discutido, ainda existe muita confusão em relação aos conceitos de clonagem (reprodutiva e terapêutica), células-tronco ( embrionárias e não embrionárias) e terapia celular bem como isso pode afetar as nossas vidas. Portanto a proposta desse artigo é o de tentar definir esses conceitos e expressar a minha posição sobre aspectos éticos não só como cientista mas também como representante de inúmeras famílias que vêem nessa nova tecnologia uma esperança futura de cura para inúmeras doenças neurodegenerativas, muitas vezes letais ou gravemente incapacitantes.

A BSTRACT - ALTHOUGH concepts such as human cloning (reproductive and therapeutic), stem cells (embryonic and non-embryonic), and stem cell therapy and how these issues may affect our lives have been extensively discussed, there is still a lot of misunderstanding. Therefore the aim of this article is to try to better explain these definitions and express my personal opinion on ethical aspects not only as a scientist but also as a representative of inumerous families who hope that this technology might represent in the future a treatment for many neurodegenerative disorders often lethal or severely disabling.

M ayana Zatz é professora-titular de G enética $H$ umana e $M$ édica do $D$ epartamento de Biologia do Instituto de Biociências (IB) da U SP, coordenadora do Centro de Estudos do G enoma H umano do IB-U SP, presidente da Associação Brasileira de D istrofia M uscular e membro da Academia Brasileira de Ciências.

Conferência feita pela autora no Instituto de Estudos Avançados da U SP no dia 19 de maio de 2004. Parte deste texto foi publicado em: Z atz, M ayana. "Clonagem e células-tronco". Cienc. Cult., jun. 2004, vol. 56, no 3, pp. 23-27, ISSN 0009-6725.

Texto recebido e aceito para publicação em 23 de junho de 2004. 